\title{
SUFFICIENCY INDEX FOR DEFINING NITROGEN RECOMMENDATION IN BRACHIARIA GRASS PASTURE
}

\author{
ÍNDICE DE SUFICIÊNCIA PARA A DEFINIÇÃO DE RECOMENDAÇÃO DE \\ NITROGÊNIO EM PASTAGEM DE CAPIM BRAQUIÁRIA
}

\author{
Flora Maria de Melo VILLAR ${ }^{1}$; Francisco de Assis de Carvalho PINTO²; \\ Dilermando Miranda da FONSECA ${ }^{3}$; Daniel Marçal de QUEIROZ ${ }^{2}$; \\ Gracielly Ribeiro de ALCÂNTARA ${ }^{1}$
}

1. Pós-graduação em Engenharia Agrícola, Universidade Federal de Viçosa - UFV, Viçosa, MG, Brasil. flora.villar.ufv@gmail.com; 2. Departamento de Engenharia Agrícola - UFV- Viçosa, MG, Brasil; 3. Departamento de Zootecnia - UFV- Viçosa, MG, Brasil.

\begin{abstract}
In addition to be absorbed by plants, nitrogen (N) applied in the soil is subject to loss by leaching, volatilization and microorganism immobilization. The spectral characteristics of plants have been used for defining the $\mathrm{N}$ fertilizer rate. However, it has been a challenge to translate the sensor readings into the $\mathrm{N}$ rate. Thus, the aim of the present study was to evaluate three spectral variables to recommend variable rate $\mathrm{N}$ fertilization in Brachiaria decumbens using the Nitrogen Sufficiency Index (NSI). The five treatments consisted of a control plot (without nitrogen application), a reference plot with a fixed $\mathrm{N}$ rate of $150 \mathrm{~kg} \mathrm{ha}^{-1}$ and three different spectral readings for applying $\mathrm{N}$ at variable rates. In the variable rate plots were initially applied a $\mathrm{N}$ rate equal to $50 \%$ of that in the reference plot, and the following rates were defined based on NSI. The three spectral variables were: a portable chlorophyll meter readings, Visible Atmospherically Resistant Index (VARI RedEdge $)$ and the ratio between Modified Chlorophyll Absorption Ratio Index and Optimized Soil Adjusted Vegetation Index (MCARI/OSAVI). The experiment was conducted in randomized block design with five replicates during three plant harvesting. The forage was harvested when the plant height was $25 \mathrm{~cm}$ in the reference plot. The variable rate treatments presented better nitrogen use efficiency than the fixed rate treatment. The portable chlorophyll meter was more suitable than the used vegetation indices to recommend variable $\mathrm{N}$ rate fertilization since their plots produced the same dry biomass matter as in the fixed rate plot with less amount of fertilizer applied.
\end{abstract}

KEYWORDS: Portable chlorophyll meter. Precision farming. Remote sensing. Spectral vegetation index. Variable rate technology.

\section{INTRODUCTION}

The livestock producers are moving to fields where the soil has lower fertility due to agriculture demands since grain crops have more financial advantage than growing pastures. To enable the livestock on agricultural land, the farmers should increase yield and competitiveness of their exploitation. A factor of pasture management that has impact in the productivity and potential for improving the economic performance of livestock activity is the nitrogen $(\mathrm{N})$ management, which has a positive effect on production and nutritional value of the forage (ANDRADE et al., 2003).

Nitrogen applied in the soil has a complex dynamic cycle because it is subject to loss by leaching, volatilization and microorganism immobilization. Thus, it is necessary to study $\mathrm{N}$ management techniques that may indicate the optimal rate of this nutrient for profit maximization of the forage production with mitigation of environmental damage.

Site specific management has been proposed by applying variable rates of agricultural inputs with possible reductions in production costs
(DURIGON, 2007). The American Potash \& Phosphate Institute (PPI), in one of its recommendation bulletin for site-specific management for corn and wheat, presented a methodology for $\mathrm{N}$ variable rate prescription based on the comparison of chlorophyll readings on a reference plot with the readings on the areas where $\mathrm{N}$ would be applied (FRANCIS; PIEKIELEK, 1999). In the reference plot is applied the maximum desired $\mathrm{N}$ rate. If the nitrogen sufficiency index (NSI) of an area, evaluated by Equation 1, is less than $95 \%$, the $\mathrm{N}$ should be applied on this area (FRANCIS; PIEKIELEK, 1999). NSI $=\frac{S M_{T S}}{S M_{T}} \times 100$

where:

NSI - nitrogen sufficiency index;

$\mathrm{SM}_{\mathrm{vr}}-$ spectral measurement on the area to be treated by variable rate application; and

$\mathrm{SM}_{\mathrm{r}}-$ spectral measurement on the reference plot.

The PPI methodology used an indirect chlorophyll portable meter as spectral measurement. However, other kind of chlorophyll correlated measurements can be exploited. Thus, the aim of the 
present study was to evaluate three spectral variables (a portable chlorophyll reading and two spectral vegetation indices) to recommend variable rate nitrogen fertilization in Brachiaria decumbens using the NSI and verify its efficiency when compared to fixed-rate application.

\section{MATERIAL AND METHODS}

The experiment was established in a forage area of the Department of Animal Science, campus of the Universidade Federal de Viçosa, in Viçosa city, Minas Gerais state, located at latitude $20^{\circ}$ 45'14" (S) and latitude $42 \circ 52$ '54" (W) with an altitude of approximately $649 \mathrm{~m}$. The experiment was carried in the period January-April 2012. The soil of the region is classified as "Latossolo Vermelho-Amarelo", according to the Brazilian soil classification system, with clay texture.

The climate type of Viçosa region is Cwb, defined as tropical of altitude with mild and rainy summer and cold and dry winter, according to Köpen classification adapted to Brazil (Golfari, 1975). Daily meteorological data of rainfall, hours of insolation, air temperature and relative humidity were obtained from the weather station of the Universidade Federal de Viçosa, which is at a distance of approximately $400 \mathrm{~m}$ from the experimental area.

The experiment was conducted on a Brachiaria decumbens field, established approximately 10 years ago, which was cut to a height of $5 \mathrm{~cm}$, and the cut biomass was removed from the plots.

The experimental design was a randomized complete block design with five replications. The treatments were allocated in plots of $3 \mathrm{~m} \mathrm{x} 3 \mathrm{~m}$. The treatments consisted of a control plot (without nitrogen application), a fixed $\mathrm{N}$ rate of $150 \mathrm{~kg} \mathrm{~N}^{-1}$ (reference plot) and three different techniques for applying $\mathrm{N}$ at variable rates. In the variable rate plots were initially applied a $\mathrm{N}$ rate equal to $50 \%$ of that in the reference plot, i.e. $75 \mathrm{~kg} \mathrm{ha}^{-1}$, and the following rates were defined based on Nitrogen Sufficiency Index (NSI) (FRANCIS; PIEKIELEK, 1999), according to Equation 1.

The NSI was calculated in two distinct dates: when the average height of plant in the reference plot was 14 and $18 \mathrm{~cm}$ for the first and second date, respectively. Plant height was the average of five random measurements within each plot. When the NSI was less than $95 \%$ in a plot, it was applied on this plot a $\mathrm{N}$ rate equal to $25 \%$ of that in the reference plot, i.e. $37.50 \mathrm{~kg} \mathrm{ha}^{-1}$. To calculate the NSI, it was used three different spectral measurements for each treatment of variable $\mathrm{N}$ rate. Thus, the treatments were:

- $\mathrm{T}_{0}$ : control plot, without $\mathrm{N}$ application;

- $\mathrm{T}_{1}$ : reference plot, application of a fixed rate of $150 \mathrm{~kg} \mathrm{ha}^{-1}$ of $\mathrm{N}$ fertilizer in the form of urea;

- $\mathrm{T}_{2}$ : variable rate plot, using the portable chlorophyll meter reading as spectral measurement;

- $\mathrm{T}_{3}$ : variable rate plot, using the vegetation index $\mathrm{VARI}_{\text {RedEdge }}{ }^{1}$ as spectral measurement, determined according to Equation 2;

- $\mathrm{T}_{4}$ : variable rate plot, using the ratio between the vegetation indices $\mathrm{MCARI}^{2}$ e $\mathrm{OSAVI}^{3}$ as spectral measurement, determined according to Equations 3 and 4.

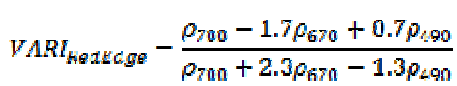

OSAVI $=\frac{\rho_{800}-\rho_{670}}{\rho_{800}+\rho_{670}+0.16} 1.16$

$M C A R I=\left[\left(\rho_{700}-\rho_{670}\right)-0.2\left(\rho_{700}-\rho_{550}\right)\right] \frac{\rho_{700}}{\rho_{670}}$

where:

$\rho_{700}-$ target reflectance at wavelength of $700 \mathrm{~nm}$; $\rho_{670}-$ target reflectance at wavelength of $670 \mathrm{~nm}$; $\rho_{490}$ - target reflectance at wavelength of $490 \mathrm{~nm}$; $\rho_{800}$ - target reflectance at wavelength of $800 \mathrm{~nm}$; $\rho_{550}-$ target reflectance at wavelength of $550 \mathrm{~nm}$. 1.Visible Atmospherically Resistant Index, proposed by Gitelson et al. (2003); 2. Modified Chlorophyll Absorption Ratio Index, proposed by Daughtry et al. (2000) ; 3. Optimized Soil Adjusted Vegetation Index, proposed by Rondeaux et al. (1996)

Before beginning this study, soil of each block was analyzed and had their fertility corrected as recommended by Alvarez V. (1999), except for N. All plots received the rate of $350 \mathrm{~kg} \mathrm{ha}^{-1}$ of superphosphate, and in the plots of block five were also applied a rate of $86 \mathrm{~kg} \mathrm{ha}^{-1}$ of potassium chloride.

The spectral variables were determined based on readings measured when plants of the reference plot $\left(\mathrm{T}_{1}\right)$ reached 14 and $18 \mathrm{~cm}$ of average height for the first and second date, respectively. In each plot, 30 leaves of 30 different forage tillers were randomly sampled for the determination of the average value of the spectral variable using the Minolta SPAD 502 portable chlorophyll meter $\left(\mathrm{T}_{2}\right)$ or using the ASD spectrometer (Analytic Spectral Devices, Boulder, USA) Field SpecPro FR with the plant probe $\left(\mathrm{T}_{3}\right.$ and $\left.\mathrm{T}_{4}\right)$. 
For dry biomass matter determination, a $1.00 \mathrm{~m}^{2}$ area of each plot was harvested by cutting the planting at $5 \mathrm{~cm}$ of height when the reference plot plants reached the average of $25 \mathrm{~cm}$ height. Subsequently, the samples were stored in paper bags and weighed to determine the green biomass weight. A sample was collected from the green biomass to be dried in an oven with forced air circulation for 72 hours at $65^{\circ} \mathrm{C}(\mathrm{CABEZAS}, 2011)$. Finally, the dried biomass sample was weighed for estimation of dry biomass matter yield in $\mathrm{kg} \mathrm{ha}^{-1}$.

The results were submitted to variance analysis and the means of dry biomass matter were compared using Duncan test at 5\% probability. These analyzes were performed in the R software.
This procedure was performed in three cycles, meaning that three plant cuts were performed. The dates of beginning and end of each cycle and the dates of data collections are shown on Table 1. On the same date of the plant cutting, the new cycle started with the application of $150 \mathrm{~kg} \mathrm{ha}^{-1}$ of $\mathrm{N}$ in the reference plots and $75 \mathrm{~kg} \mathrm{ha}^{-1}$ in the variable rate plots.

At the end of the three experimental cycles, the nitrogen use efficiency (NUE) was evaluated for each treatment. The NUE was evaluated as the ratio between total applied nitrogen and total dry biomass matter in the whole period of the experiment.

Table 1: Dates of beginning and end of each cycle, and dates of data collection based on the plant height of the reference plot

\begin{tabular}{llll}
\hline & $1^{\text {st }}$ Cycle & $2^{\text {nd }}$ Cycle & $3^{\text {rd }}$ Cycle \\
\hline Beginning & $23 / 01 / 2012$ & $17 / 02 / 2012$ & $14 / 03 / 2012$ \\
Cut & $16 / 02 / 2012$ & $14 / 03 / 2012$ & $09 / 04 / 2012$ \\
\hline $14 \mathrm{~cm}$ & $03 / 02 / 2012$ & $29 / 02 / 2012$ & $28 / 03 / 2012$ \\
$18 \mathrm{~cm}$ & $08 / 02 / 2012$ & $07 / 03 / 2012$ & $03 / 04 / 2012$ \\
\hline
\end{tabular}

\section{RESULTS AND DISCUSSION}

In the first cycle, the total precipitation was $171.0 \mathrm{~mm}$ with 199.7 hours of insolation. In the second cycle, the total precipitation was $6.5 \mathrm{~mm}$ with 218.6 hours of insolation. In the third cycle, the total precipitation was $120.5 \mathrm{~mm}$ with 141.5 hours of insolation (Figure 1). Although the highest amount of rainfall happened during the first cycle, it was not well distributed, concentrating at the beginning and at the end of the cycle. In the other hand, the precipitation of the third cycle was well distributed throughout the period, featuring the late summer and early fall season. In the second cycle, there was low precipitation, atypical situation for the summer because there was almost a month of drought.

The highest average yield of dry biomass matter and the highest average height at cut happened in the third cycle (Figure 2). This was a cycle with high and well distributed rainfall, what contributed to the $\mathrm{N}$ uptake by plants with consequent increase of dry matter and plant height. Another factor that may have contributed was the $\mathrm{N}$ residual effect of the treatments in the previous cycles.

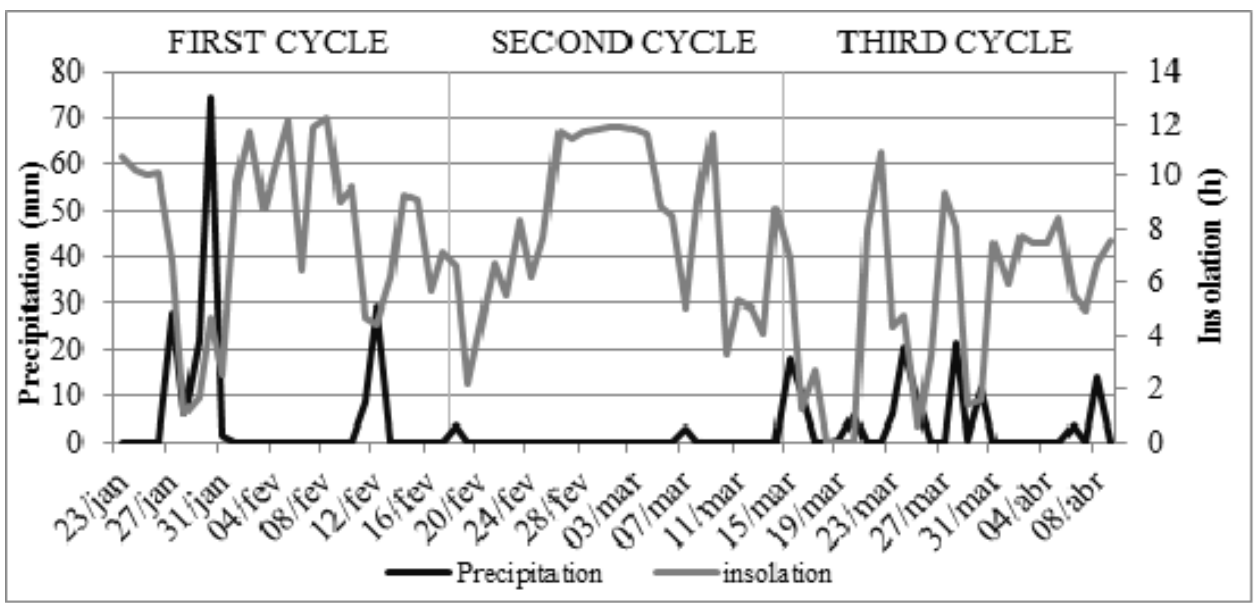

Figure 1. Daily rainfall and hours of insolation during the three experimental cycles. 


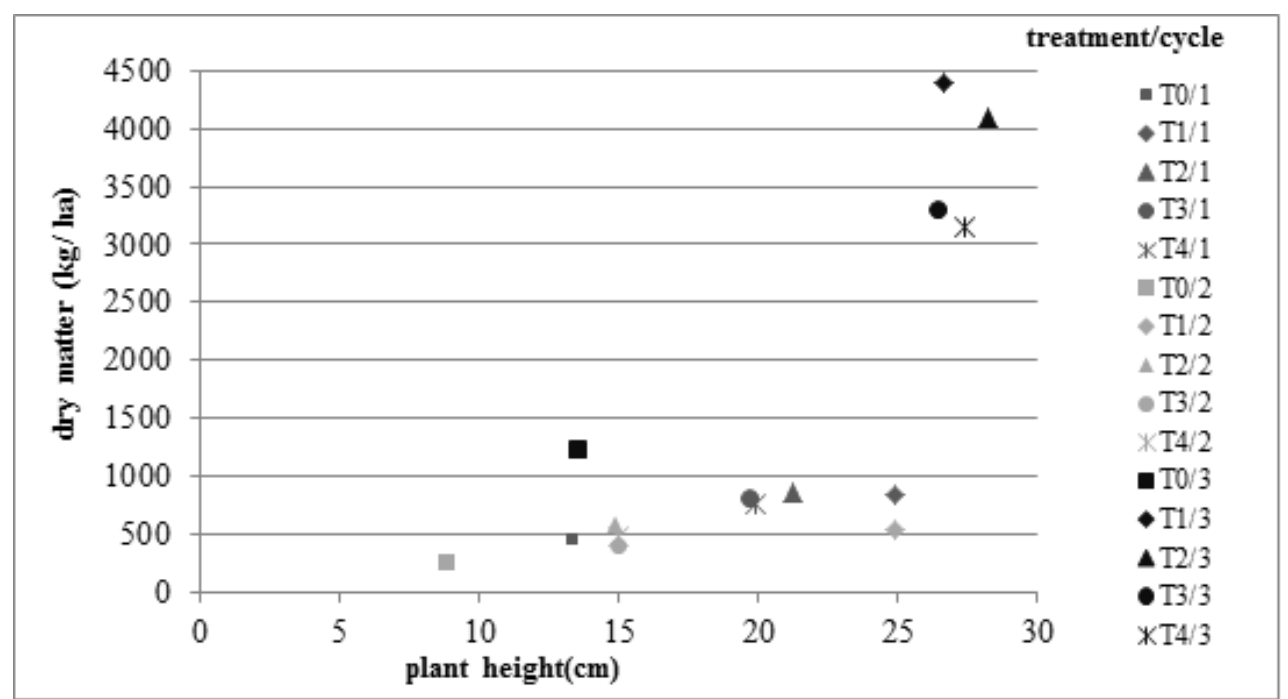

Figure 2. Scatter plot of average dry matter production and average height reached by the plants at the end of each cycle in each treatment.

The forage production depends not only on the availability of nutrients, but also on factors defined by the genetic of the species, climatic factors such as temperature, sunlight and rainfall, among others (MOTA et al., 2010; OLIVEIRA et al., 2010). Usually, the lowest yields of tropical forages are recorded in winter, reflecting effects of low precipitation this time of year. The low temperature and hours of insolation also determine physiological changes affecting the growth of grasses (BAUER et al., 2011).

The results of dry biomass matter produced by Braquiaria grass and the average amount of nitrogen fertilizer applied in each treatment are shown in Tables 2, 3 and 4 for the three experimental cycles.

Table 2. Means of dry biomass matter and $\mathrm{N}$ rate applied in the first studied cycle

\begin{tabular}{|c|c|c|c|c|c|}
\hline Treatment & $\begin{array}{l}\text { Nitrogen } \\
\text { at the } \\
\text { beginning }_{\left(\mathrm{kg} \mathrm{ha}^{-1}\right)}\end{array}$ & $\begin{array}{l}\text { Plot } \\
\text { number } \\
\text { treated } \\
\text { at } 14 \mathrm{~cm}\end{array}$ & $\begin{array}{l}\text { Plot } \\
\text { number } \\
\text { treated } \\
\text { at } 18 \mathrm{~cm}\end{array}$ & $\begin{array}{l}\text { Total } \\
\text { nitrogen } \\
\text { applied } \\
\left(\mathrm{kg} \mathrm{ha}^{-1}\right)\end{array}$ & $\begin{array}{l}\text { Dry } \\
\text { Matter* }\end{array}$ \\
\hline$\overline{T_{2}}$ & 75 & 3 & 2 & 112.5 & $856.7 \mathrm{a}$ \\
\hline$T_{1}$ & 150 & 0 & 0 & 150 & $837.7 \mathrm{a}$ \\
\hline $\mathbf{T}_{\mathbf{3}}$ & 75 & 0 & 0 & 75 & $822.3 \mathrm{a}$ \\
\hline $\mathbf{T}_{4}$ & 75 & 0 & 0 & 75 & $762.6 \mathrm{a}$ \\
\hline $\mathbf{T}_{\mathbf{0}}$ & 0 & 0 & 0 & 0 & $468.9 \quad b$ \\
\hline
\end{tabular}

$\mathrm{T}_{0}-$ without $\mathrm{N} ; \mathrm{T}_{1}-$ reference plot with a fixed rate; $\mathrm{T}_{2}$ - variable rate using $\mathrm{SPAD} ; \mathrm{T}_{3}-$ variable rate using VARI $\mathrm{RedEdge}_{2} ; \mathrm{T}_{4}-$ variable rate using MCARI/ OSAVI; * Means followed by the same letter do not differ at $5 \%$ probability by Duncan test.

Table 3. Means of dry biomass matter and $\mathrm{N}$ rate applied in the second studied cycle

\begin{tabular}{|c|c|c|c|c|c|c|}
\hline Treatment & $\begin{array}{l}\text { Nitrogen } \\
\text { at the } \\
\text { beginning } \\
\left(\mathrm{kg} \mathrm{ha}^{-1}\right)\end{array}$ & $\begin{array}{l}\text { Plot } \\
\text { number } \\
\text { treated } \\
\text { at } 14 \mathrm{~cm}\end{array}$ & $\begin{array}{l}\text { Plot } \\
\text { number } \\
\text { treated } \\
\text { at } 18 \mathrm{~cm}\end{array}$ & $\begin{array}{l}\text { Total } \\
\text { nitrogen } \\
\text { applied } \\
\left(\mathrm{kg} \mathrm{ha}^{-1}\right)\end{array}$ & $\begin{array}{l}\text { Dry } \\
\text { Matter* } \\
\left(\mathbf{k g ~ h a}^{-1}\right)\end{array}$ & \\
\hline $\mathbf{T}_{2}$ & 75 & 1 & 0 & 82.5 & $592.04 \mathrm{a}$ & \\
\hline $\mathbf{T}_{1}$ & 150 & 0 & 0 & 150 & $540.58 \mathrm{a} \mathrm{b}$ & \\
\hline $\mathbf{T}_{4}$ & 75 & 1 & 1 & 90 & 477.28 & $\mathrm{bc}$ \\
\hline $\mathbf{T}_{3}$ & 75 & 0 & 1 & 82.5 & 399.86 & $\mathrm{c}$ \\
\hline $\mathbf{T}_{0}$ & 0 & 0 & 0 & 0 & 258.36 & $\mathrm{~d}$ \\
\hline
\end{tabular}


Table 4. Means of dry biomass matter and $\mathrm{N}$ rate applied in the third studied cycle

\begin{tabular}{|c|c|c|c|c|c|}
\hline Treatment & $\begin{array}{l}\text { Nitrogen } \\
\text { at the } \\
\text { beginning } \\
\left(\mathrm{kg} \mathrm{ha}^{-1}\right)\end{array}$ & $\begin{array}{l}\text { Plot } \\
\text { numbers } \\
\text { treated } \\
\text { at } 14 \mathrm{~cm} \\
\end{array}$ & $\begin{array}{l}\text { Plot } \\
\text { numbers } \\
\text { treated } \\
\text { at } 18 \mathrm{~cm} \\
\end{array}$ & $\begin{array}{l}\text { Total } \\
\text { nitrogen } \\
\text { applied } \\
\left(\mathrm{kg} \mathrm{ha}^{-1}\right)\end{array}$ & $\begin{array}{l}\text { Dry } \\
\text { Matter* } \\
\left(\mathbf{k g ~ h a}^{-1}\right)\end{array}$ \\
\hline$T_{1}$ & 150 & 0 & 0 & 150 & $4400.8 \mathrm{a}$ \\
\hline $\mathbf{T}_{2}$ & 75 & 2 & 2 & 105 & $4100.6 \mathrm{a}$ \\
\hline $\mathbf{T}_{3}$ & 75 & 3 & 1 & 105 & $3302.8 \mathrm{~b}$ \\
\hline $\mathbf{T}_{4}$ & 75 & 0 & 0 & 75 & $3143.0 \mathrm{~b}$ \\
\hline $\mathbf{T}_{0}$ & 0 & 0 & 0 & 0 & 1243.6 \\
\hline
\end{tabular}

In the first cycle, only the variable rate treatment that used SPAD reading as spectral variable for $\mathrm{N}$ recommendation needed fertilizer in addition to the initial application of $75 \mathrm{~kg} \mathrm{ha}^{-1}$. On the first date of application, according to the NSI indication, it was applied the average of $22.5 \mathrm{~kg} \mathrm{ha}^{-1}$ (three of five plots received $37.5 \mathrm{~kg} \mathrm{ha}^{-1}$ of nitrogen fertilizer) for $\mathrm{T}_{2}$. On the second date of application, it was applied the average of $15 \mathrm{~kg} \mathrm{ha}^{-1}$ (two of five plots received $37.5 \mathrm{~kg} \mathrm{ha}^{-1}$ of nitrogen fertilizer) for $\mathrm{T}_{2}$. With these amounts of fertilizer applied, the dry biomass matter yield was $856.7 \mathrm{~kg} \mathrm{ha}^{-1}$, not significantly different from the yields obtained by the treatment that received a fixed rate of fertilizer and from the others variable rate treatments.

There was a period of rain just after the beginning of the first cycle that may have caused leaching of $\mathrm{N}$, contributing to not $\mathrm{N}$ uptake by plants. Thus, the variable rate treatment plots, that received less $\mathrm{N}$ before this rainfall and the following applications were parceled as in the SPAD treatment, had the same dry matter production as that of the reference plots even applying less $\mathrm{N}$.

The lower fertilizer recommendation for variable rate treatments can be attributed mainly the uneven rainfall distribution in the first cycle, which limited the $\mathrm{N}$ uptake by plants. The methodology was effective to identify that the plant did not need more N. If the fertilizer was applied in this case, it could cause more losses and increased pollution of the environment. Thus, if the recommendation decision was done only based on dry biomass production, any treatment could be used for recommendation of nitrogen fertilization. However, since there was no statistical difference between the dry mass production among the treatments that received $\mathrm{N}$, the variable rate treatments presented economic and environmental advantages over the fixed rate $\left(T_{1}\right)$ in the first cycle.

In the second cycle, according to the NSI values, all variable rate treatments needed fertilizer in addition to the initial application of $75 \mathrm{~kg} \mathrm{ha}^{-1}$.
Both variable rate treatments SPAD and VARI $I_{\text {RedEdge }}$ received the average of $7.5 \mathrm{~kg} \mathrm{ha}^{-1}$ of $\mathrm{N}$ at first and at second date of application, respectively. The variable rate treatment MCARI/OSAVI received the average of $7.5 \mathrm{~kg} \mathrm{ha}^{-1}$ of $\mathrm{N}$ at both dates, when the plant height in the reference plot was 14 and $18 \mathrm{~cm}$.

There was too low precipitation during this second cycle, only $6.5 \mathrm{~mm}$, what may have contributed to the lower dry biomass matter production recorded when compared with the first cycle. Thus, also in this case, the application of fertilizer in a variable rate tended to be the factor that contributes to better efficiency for the $\mathrm{N}$ management since urea based fertilizer is more likely to be volatilized with low rainfall and high temperatures.

In this second cycle, the best treatment for recommendation of nitrogen fertilization was $T_{1}$ that used SPAD readings as spectral variable since it reached the highest dry biomass matter yield among the variable rate treatments, and its yield was equal to the reference plot even using lesser amount of fertilizer

The third experimental cycle presented the highest dry biomass matter yield and also presented the most uniform rainfall distribution. Vitor et al. (2009) and Mota et al. (2010) showed the importance of the amount of available water in the soil and plant system for the forage plant $\mathrm{N}$ absorption and production. Those both studies worked with the same forage (elephant grass) and used the same combination of four $\mathrm{N}$ rate $(100,300$, 500 and $700 \mathrm{~kg} \mathrm{ha}^{-1}$ year) and amount of irrigation water depth $(0,20,40,80,100$ and $120 \%$ of the reference evapotranspiration). Vitor et al. (2009) found that the production of dry biomass matter increased linearly in relation to nitrogen levels and irrigation water depth. Mota et al. (2010) found the highest production when it was supplied a water depth equivalent to $100 \%$ of the reference evapotranspiration and was applied $500 \mathrm{~kg} \mathrm{ha}^{-1}$ year of $\mathrm{N}$. 
In the third cycle, the variable rate treatments that used SPAD and $\mathrm{VARI}_{\text {RedEdge }}$ as spectral measurement needed fertilizer in addition to the initial application of $75 \mathrm{~kg} \mathrm{ha}^{-1}$, according to the NSI values. The variable rate treatment SPAD received the average of $15 \mathrm{~kg} \mathrm{ha}^{-1}$ and later more 15 $\mathrm{kg} \mathrm{ha}^{-1}$ of $\mathrm{N}$, when the average plant height in the reference plot was 14 and $18 \mathrm{~cm}$, respectively. The variable rate treatment $\mathrm{VARI}_{\mathrm{RedEdge}}$ received the average of $22.5 \mathrm{~kg} \mathrm{ha}^{-1}$ and $7.5 \mathrm{~kg} \mathrm{ha}^{-1}$ of $\mathrm{N}$ on the first and second date, respectively. Thus, both treatments SPAD and VARI $\mathrm{RedEdge}_{\text {e }}$ received the same total amount of fertilizer $\left(105 \mathrm{~kg} \mathrm{ha}^{-1}\right)$ at the end of the cycle, however their dry biomass matter production were different from each other, and the highest yield was recorded when using the SPAD. The highest rate applied when the plant height was $14 \mathrm{~cm}$, March $28^{\mathrm{st}}$, for the VARI $\mathrm{VedEdge}_{\text {treatment }}$ may have led to $\mathrm{N}$ leaching before the plant could absorb the entire applied $\mathrm{N}$ since there was a heavy rainfall after this date. Leaching of $\mathrm{N}$ cause environment contamination and it should be avoided.

The variable rate treatment that used SPAD reading was the only one that did not differ from the reference plot in all three experimental cycles (Tables 2, 3 and 4). Regardless of weather conditions, although the SPAD variable rate treatment used smaller amount of $\mathrm{N}$ fertilizer, it produced the same amount of dry biomass matter as produced by the reference treatment. Thus, the SPAD reading is the recommended spectral measurement for variable $\mathrm{N}$ rate recommendation in the context of the studied methodology.

The SPAD readings have the disadvantage to be a contact sensor while the vegetation indices could be used as canopy measurements. The SPAD reading adoption could not be feasible due to the large number of sample points needed to draw up a map of the variable rate application. Webster \& Oliver (1992) showed that, to build a map by kriging sample interpolation, a minimum of 150 to 200 point samples are required for precise estimating of the variogram. Despite the SPAD reading limitation for building a fertilizer recommendation map, it can be useful to improve the nitrogen management in a system such as the rotational grazing of pasture paddock by adopting one $\mathrm{N}$ rate for each paddock based on the NSI.

The dry matter produced by treatments $T_{3}$ and $\mathrm{T}_{4}$ was statistically different from those of treatment $T_{2}$ in the second and third cycles, indicating that using the vegetation indices as spectral measurements was not as effective as using the SPAD. The vegetation indices were developed for canopy, and, in their conception, the authors looked for minimizing the soil and atmosphere effects in plant reflectance. However, in this study, these indices were used as leaf measurement, having no soil interference. Although the worse results of the vegetation indices than SPAD, studies should be done with these indices in a canopy measurement. Canopy measurements would play an important role for adopting the studied methodology since it would either be less time consuming or have more sample rate acquisition by doing readings without stop.

The nitrogen use efficiency (NUE) of the Braquiaria grass during the three experimental cycles is shown in Table 5. The NUE was the ratio between total applied nitrogen and total dry biomass matter in the whole period of the experiment.

Table 3. Total applied nitrogen $\left(\mathrm{N}_{\mathrm{t}}\right)$, total dry biomass matter $\left(\mathrm{DM}_{\mathrm{t}}\right)$ and nitrogen use efficiency (NUE) during the three experimental cycles

\begin{tabular}{llll}
\hline Treatment & $\begin{array}{l}\mathbf{N}_{\mathbf{t}} \\
\left(\mathbf{k g ~ h a}^{-\mathbf{1}}\right)\end{array}$ & $\begin{array}{l}\mathbf{D M}_{\mathbf{t}} \\
\left(\mathbf{k g ~ h a}^{-\mathbf{1}}\right)\end{array}$ & $\mathbf{N U E}$ \\
\hline $\mathrm{T}_{1}$ & 450 & $5,779.08$ & 12.84 \\
$\mathrm{~T}_{2}$ & 300 & $5,849.34$ & 19.50 \\
$\mathrm{~T}_{3}$ & 262.5 & $4,524.96$ & 17.24 \\
$\mathrm{~T}_{4}$ & 240 & $4,382.88$ & 18.26 \\
\hline
\end{tabular}

$\mathrm{T}_{1}$ - reference plot with a fixed rate; T2 - variable rate using SPAD; T3 - variable rate using $\mathrm{VARI}_{\text {RedEdge}}$; T4 - variable rate using MCARI/ OSAVI

The treatment that used the SPAD reading as spectral measurement was the most efficient $\mathrm{N}$ use followed by the others variable rate treatments. The SPAD readings plots required $33 \%$ less fertilizer than the fixed rate plot. The fixed $\mathrm{N}$ rate treatment was the lowest efficient of $\mathrm{N}$ using; even producing the second highest total amount of dry biomass matter.

The results showed that the use of well fertilized reference plot for $\mathrm{N}$ recommendation in the rest of area can reduce the losses in the complex $\mathrm{N}$ cycle. The challenge when using any spectral based sensors for $\mathrm{N}$ recommendation is how to 
translate from the sensor readings into the nitrogen fertilizer rate. According to Samborski et al. (2009) review paper, the calibration of the sensor reading with $\mathrm{N}$ recommendation has been difficult in part because of the variations in the chlorophyll estimation values due to soil properties, growth stage, sampling procedures, cultivar and seasonal effects. In the present work, growth stage, sampling procedures and cultivar were controlled factors by methodological procedure, as well as the soil properties were controlled by the experimental design in randomized block. The seasonal effects such as water supply, temperature and solar irradiance were accounted in the definition of the $\mathrm{N}$ rates by comparing the sensor reading in the variable rate plots with the readings in a reference plot. Thus, the results showed that using a well fertilizer reference plot mitigated the seasonal effects and, consequently, improved the NUE.

\section{CONCLUSIONS}

The variable $\mathrm{N}$ rate recommendation based on the Nitrogen Sufficiency Index presents better results than a fixed rate for the Brachiaria decumbens pasture.

For spectral leaf measurements, the portable chlorophyll meter is more suitable than vegetation indices to recommend variable $\mathrm{N}$ rate fertilization in Brachiaria decumbens pasture.

\section{ACKNOWLEDGEMENTS}

The authors gratefully acknowledge the financial support of this project by the Brazilian Agencies "Fundação de Amparo à Pesquisa de Minas Gerais" - FAPEMIG, and "Conselho Nacional de Desenvolvimento Científico e Tecnológico" - CNPQ.

RESUMO: Além de ser absorvido pelas plantas, o nitrogênio $(\mathrm{N})$ aplicado no solo está sujeito à perda por lixiviação, volatilização e imobilização pelos microrganismos. As características espectrais das plantas têm sido usadas para definir a taxa de aplicação de fertilizante nitrogenado. No entanto, tem sido um desafio transformar as leituras dos sensores em taxas de N. Assim, o objetivo do presente estudo foi avaliar três variáveis espectrais para recomendar adubação nitrogenada a taxa variável em Brachiaria decumbens, usando o Índice de Suficiência de Nitrogênio (NSI). Os cinco tratamentos consistiram de uma testemunha (sem aplicação de $\mathrm{N}$ ), de uma parcela de referência com uma taxa de $\mathrm{N}$ fixa de $150 \mathrm{~kg} \mathrm{ha}^{-1}$ e três leituras espectrais diferentes para a aplicação de $\mathrm{N}$ a taxas variáveis. Na taxa variável, as parcelas receberam inicialmente uma taxa de $\mathrm{N}$ igual a $50 \%$ da parcela de referência, e as seguintes taxas foram definidas com base no NSI. As três variáveis espectrais foram: as leituras do medidor portátil de clorofila (SPAD), Visible Atmospherically Resistant Index (VARIRedEdge) e a razão entre Modified Chlorophyll Absorption Ratio Index e Optimized Soil Adjusted Vegetation Index (MCARI/OSAVI). O experimento foi conduzido em delineamento em blocos casualizados, com cinco repetições durante três colheitas da planta. A forragem foi colhida quando a altura da planta atingiu $25 \mathrm{~cm}$ na parcela de referência. Os tratamentos a taxa variável apresentaram melhor eficiência de uso de $\mathrm{N}$ do que o tratamento a taxa fixa. $\mathrm{O}$ medidor portátil de clorofila foi mais adequado que os índices de vegetação usados para recomendar a adubação nitrogenada à taxa variada uma vez que suas parcelas produziram a mesma massa seca que na parcela a taxa fixa com uma menor quantidade de $\mathrm{N}$ aplicado.

PALAVRAS-CHAVE: Agricultura de precisão. Sensoriamento remoto. Taxa variável. Índices de vegetação. Clorofilômetro portátil.

\section{REFERENCES}

ALVAREZ V., V. H. R., A. C.; GUIMARÃES, P. T. G. Recomendações para o uso de corretivos e fertilizantes em Minas Gerais. Viçosa: Comissão de Fertilidade do Solo do Estado de Minas Gerais. CFSEMG, 1999. 359p.

ANDRADE, A. C.; FONSECA, D. M. D.; QUEIROZ, D. S.; SALGADO, L. T.; CECON, P. R. Adubação nitrogenada e potássica em capim-elefante (Pennisetum purpureum Schum. cv. Napier). Ciência agrotécnica, p. 1643-1651, 2003.

BAUER, M. D. O.; PACHECO, L. P. A.; CHICHORRO, J. F.; VASCONCELOS, L. V.; PEREIRA, D. F. C. Produção e características estruturais de cinco forrageiras do gênero brachiaria sob intensidades de cortes intermitentes. Ciência Animal Brasileira, Goiânia, v. 12, n. 1, 2011. 
CABEZAS, W. A. R. L. Manejo de gramíneas cultivadas em forma exclusiva e consorciada com B. ruziziensis e eficiência do nitrogênio. Revista Brasileira de Milho e Sorgo, Sete Lagas, v. 10, n. 2, p. 130-145, 2011.

DAUGHTRY, C. S. T.; WALTHALL, C. L.; KIM, M. S.; DE COLSTOUN, E. B.; MCMURTREY III, J. E. Estimating Corn Leaf Chlorophyll Concentration from Leaf and Canopy Reflectance. Remote Sensing of Environment, New York, v. 74, n. 2, p. 229-239, 2000. http://dx.doi.org/10.1016/S0034-4257(00)00113-9

DURIGON, R. Aplicação de técnicas de manejo localizado na cultura do arroz irrigado (Oryza Sativa L.). 2007. 150 f. (Tese de Doutorado em Engenharia Agrícola). Universidade Federal de Santa Maria, Santa Maria, 2007.

FRANCIS, D. D.; PIEKIELEK, W. P. Assessing Crop Nitrogen Needs with Chlorophyll Meters. SSMG-12: 4 p. 1999.

GITELSON, A. A.; VIÑA, A.; ARKEBAUER, T. J.; RUNDQUIST, D. C.; KEYDAN, G.; LEAVITT, B. Remote estimation of leaf area index and green leaf biomass in maize canopies. Geophys. Res. Lett., v. 30, n. 5, p. 1248, 2003. http://dx.doi.org/10.1029/2002GL016450

GOLFARI, L. Zoneamento Ecológico do estado de Minas Gerais. Belo Horizonte: Centro de Pesquisa Florestal da Região do Cerrado: 1975. 65p.

MOTA, V. J. G.; REIS, S. T. D.; SALES, E. C. J. D.; JÚNIOR, V. R. R.; OLIVEIRA, F. G. D.; WALKER, S. F.; MARTINS, C. E.; CÓSER, A. C. Lâminas de irrigação e doses de nitrogênio em pastagem de capimelefante no período seco do ano no norte de Minas Gerais. Revista Brasileira de Zootecnia, Viçosa, v. 39, n. 6, p. 1191-1199, 2010.

OLIVEIRA, A. P. P.; ROSSIELLO, R. O. P.; GALZERANO, L.; COSTA JÚNIOR, J. B. G.; SILVA, R. P.; MORENZ, M. J. F. Respostas do capim-Tifton 85 à aplicação de nitrogênio: cobertura do solo, índice de área foliar e interceptação da radiação solar. Arquivo Brasileiro de Medicina Veterinária e Zootecnia, Belo Horizonte, v. 62, p. 429-438, 2010. http://dx.doi.org/10.1590/S0102-09352010000200024

RONDEAUX, G.; STEVEN, M.; BARET, F. Optimization of soil-adjusted vegetation indices. Remote Sensing of Environment, New York, v. 55, n. 2, p. 95-107, 1996. http://dx.doi.org/10.1016/00344257(95)00186-7

SAMBORSKI, S. M.; TREMBLAY, N.; FALLON, E. Strategies to Make Use of Plant Sensors-Based Diagnostic Information for Nitrogen Recommendations. Agronomy Journal, Madison, v. 101, n. 4, 2009.

VITOR, C. M. T.; FONSECA, D. M. D.; CÓSER, A. C.; MARTINS, C. E.; JÚNIOR, D. D. N.; JÚNIOR, J. I. R. Produção de matéria seca e valor nutritivo de pastagem de capim-elefante sob irrigação e adubação nitrogenada. Revista Brasileira de Zootecnia, Viçosa, v. 38, n. 3, p. 435-442, 2009.

WEBSTER, R.; OLIVER, M. A. Sample adequately to estimate variograms of soil properties. Journal of Soil Science, Oxford, v. 43, n. 177-192, 1992. 